\title{
Imaging features of an intraosseous arteriovenous malformation in the tibia
}

\author{
Hong-Hau Wang ${ }^{1,2}$, MD, Tsu-Te $\underline{\text { Yeh }}^{3}$, MD, Yu-Chun $\underline{\text { Lin }}^{4}$, MD, Guo-Shu Huang ${ }^{2}$, MD
}

\begin{abstract}
Primary intraosseous arteriovenous malformations (AVMs) are rare and have only been occasionally reported. We herein report a histologically proven case of primary intraosseous AVM in the tibia, which mimicked a fibrous tumour on radiography. This presentation carries a risk of triggering acute large haemorrhage through unnecessary biopsy. In intraosseous AVM, the magnetic resonance (MR) imaging features typical of a soft tissue AVM are absent, making diagnosis difficult. In this report, peculiar MR features in the presence of a connecting vessel between the normal deep venous system of the lower extremity and the tumour provide a clue for the early diagnosis of primary intraosseous AVM.
\end{abstract}

Keywords: intraosseous arteriovenous malformation, magnetic resonance imaging, tibia

\section{INTRODUCTION}

Primary intraosseous arteriovenous malformations (AVMs) are rare and make up less than $1 \%$ of all vascular tumours of the bone. ${ }^{(1)}$ Most of them occur in the craniofacial bones. The occurrence of AVMs in other skeletal sites, including the tibia, femur, humerus, radius and spine, has been described in only nine cases to date. ${ }^{(1-7)}$ Herein, we report a histologically proven case of primary intraosseous AVM in the tibia. On radiography, the mass presented as a well-defined, mixed osteolytic and sclerotic lesion mimicking a fibrous tumour. However, peculiar magnetic resonance $(M R)$ imaging features in the presence of a connecting vessel between the normal deep venous system of the lower extremity and the tumour provide a clue for the early diagnosis of primary intraosseous AVM. To the best of our knowledge, this peculiar appearance on MR imaging has never been reported.

\section{CASE REPORT}

A 20-year-old woman presented to our outpatient orthopaedic surgery clinic with a one-year history of intermittent left leg pain. However, there was no history of antecedent trauma or illness. The past medical histories of the patient and her family were unremarkable. Results from laboratory tests were normal. Physical examination showed no other abnormalities such as discolouration, swelling, or bruising of the skin or soft tissue of her left leg.

Figs. 1-4 show our imaging findings. No identifiable periosteal reaction, cortical thinning or soft tissue mass was noted in our patient. Based on the location of the lesion, the age of the patient and the imaging features observed, a fibrous tumour was the first clinical impression. Microscopic histological examination revealed intraosseous vascular proliferation composed of crowded blood vessels, replacing the marrow cavity, accompanied by a distorted vascular wall and abundant fibrous tissues (Fig. 5a). Masson's trichrome staining revealed the presence of elastic laminae and fibres (Fig. 5b). The histological

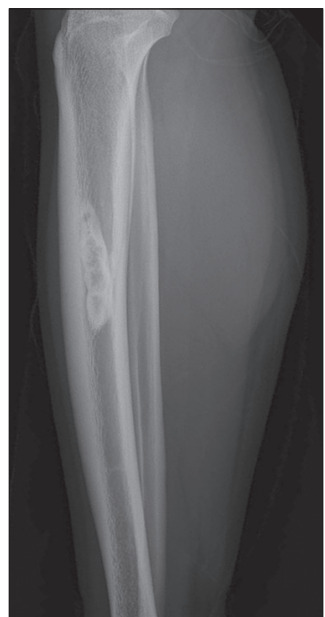

Fig. 1 Lateral radiograph of the left lower extremity shows a central, longitudinally oriented medullary lytic lesion, with a thick sclerotic margin in the mid-diaphyseal region of the tibia.

features of this vascular anomaly in our patient are consistent with those of an intraosseous AVM. Our patient underwent resection of the intraosseous lesion and remained disease-free six months post operation.

\section{DISCUSSION}

Vascular anomalies are classified as haemangiomas and vascular malformations. The most commonly used system for biological classifications of vascular anomalies is that by Mulliken and Glowacki. ${ }^{(8,9)}$ This system categorises vascular anomalies into either tumours (principally haemangiomas) or malformations, based on clinical and histological findings. Vascular malformations may present at birth and enlarge proportionately with the growth of the child. They are the result of errors in morphogenesis and are divided into subtypes such as capillary, venous, lymphatic, arterial and combined forms, based on the constituent vessels involved. Malformations may be further subcategorised based on flow characteristics. ${ }^{(10-13)}$ High-flow

${ }^{1}$ Department of Radiology, Tri-Service General Hospital Songshan Branch, ${ }^{2}$ Department of Radiology, ${ }^{3}$ Department of Orthopedics, ${ }^{4}$ Department of Pathology, Tri-Service General Hospital, National Defense Medical Center, Taipei, Taiwan, Republic of China

Correspondence: Dr Guo-Shu Huang, Professor, Department of Radiology, Tri-Service General Hospital, National Defense Medical Center, No 325, Sec 2, Cheng-Kung Road, Neihu 114, Taipei, Taiwan, Republic of China. gsh5@seed.net.tw 


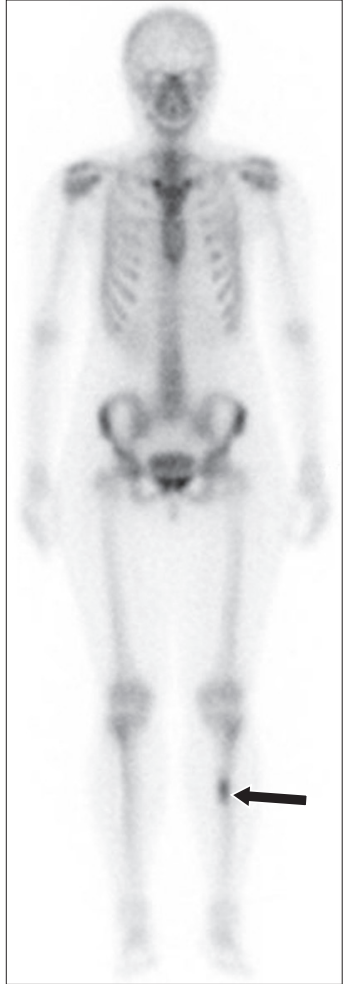

Fig. 2 Whole body bone scan with ${ }^{99 m}$ technetium-methylene diphosphonate shows an increased uptake of technetium over the mid-diaphyseal region of the left tibia (arrow).

lesions consist of any malformation with an arterial component (e.g. AVMs and arteriovenous fistulas). Low-flow lesions refer to capillary, lymphatic and venous malformations.

AVMs contain well-formed arterial and venous elements that communicate directly, rather than through a normal capillary network. They are distinguished from other vascular lesions by the triad of dilated feeding arteries, enlarged draining veins and early filling of these veins. Histologically, the presence of arteries, arterioles, or both as an integral part of the AVMs (demonstrated using Verhoeff's elastic stain) is often used as a diagnostic criterion for differentiating AVMs from haemangiomas.

While AVMs often involve the soft tissue and bone, primary intraosseous AVMs that first occur within the bone are extremely rare. Most cases of primary intraosseous AVMs occur in the mandible, maxilla and zygoma. The occurrence of primary intraosseous AVMs in other skeletal sites, including the tibia, femur, humerus, radius and spine, has been described in only nine cases to date (Table I). ${ }^{(1-7)}$ Based on these reports, primary intraosseous AVMs occurred at all ages, at the mean age of 21 (range 7-59) years; however, all but one of the patients were younger than 30 years old. ${ }^{(1-7)}$ Intraosseous haemangiomas are reported in older patients, with the peak diagnosis being made in patients in their fifties. The male to female ratio of primary intraosseous AVM incidence is 4:6, which is similar to that of intraosseous haemangioma incidence. A total of eight cases (including the present case) reported the occurrence of primary intraosseous AVMs in the long tubular bones of the extremities, and another two cases reported AVM occurrence in the vertebra of the spine. ${ }^{(1-7)}$
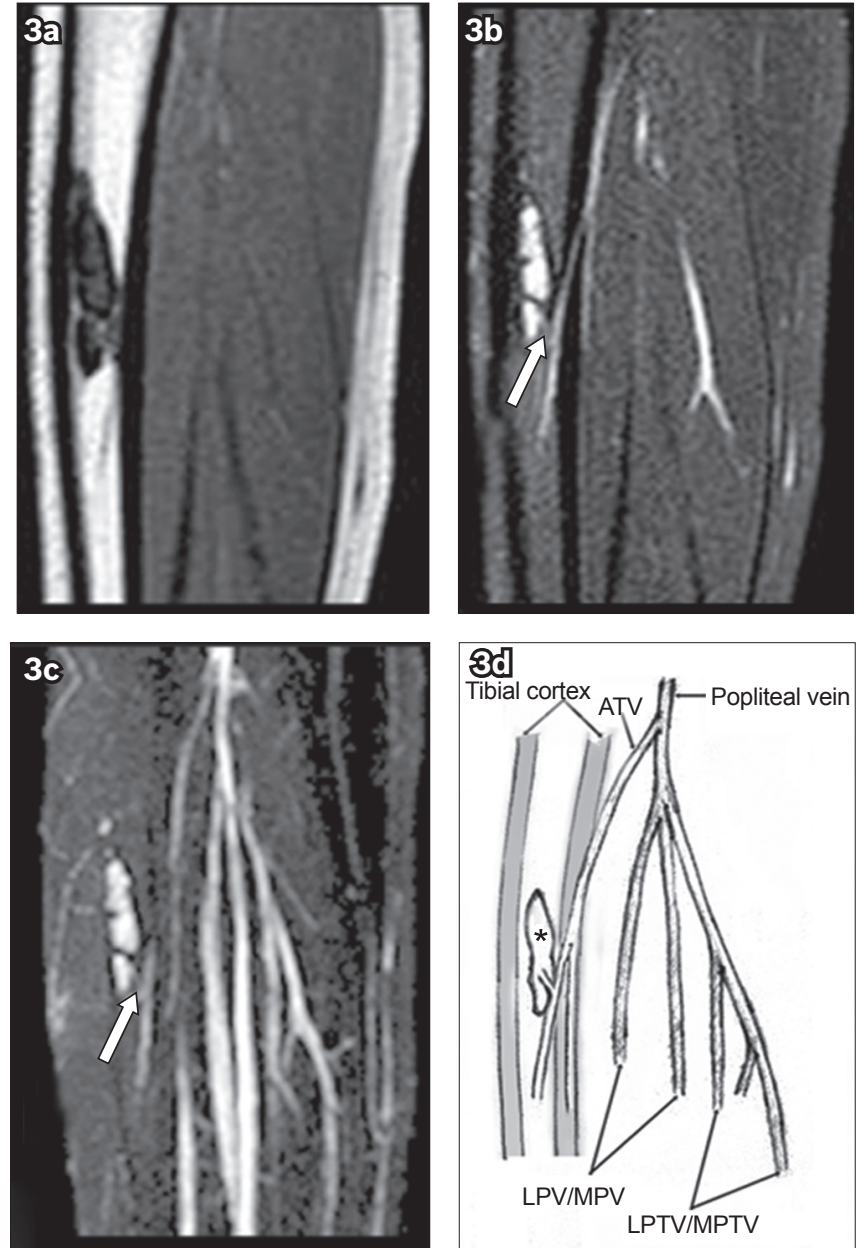

Fig. 3 (a) Sagittal T1-W MR image of the left lower extremity shows a geographic isointense lesion with a hypointense margin in the middiaphyseal region of the tibia. (b) Sagittal fat-saturated T2-W MR image shows a geographic hyperintense lesion with a hypointense margin. A connecting vessel (arrow) between the normal venous system of the lower extremity (the branch of the anterior tibial vein) and the lower pole of the lesion is also seen. (c) Sagittal maximum intensity projection reformatted image shows the connecting vessel (arrow) and the lesion. (d) A corresponding anatomic drawing depicts the lesion (asterisk), connecting vessel, tibial cortex and normal venous system of the lower extremity. ATV: anterior tibial vein; LPTV/MPTV: lateral/medial posterior tibial vein; LPV/ MPV: lateral/medial peroneal vein

The clinical manifestations of primary intraosseous AVMs are protean. Based on the nine reported cases, painful sensation over the affected area is the most common presentation, occurring in nine out of ten patients, while four in ten patients present with a pulsatile mass in the area of interest. ${ }^{(1-7)}$ However, while primary intraosseous AVMs can be associated with skin discolouration, swelling and bruising, or on rare occasions, cause high-output cardiac failure, it can also be completely asymptomatic.

On radiography, most primary intraosseous AVMs of long tubular bones are described as a central, longitudinally oriented, medullary lytic geographic lesion, occasionally accompanied by sclerotic margins. A hypertrophic nutrient artery groove, appearing as longitudinal radiolucency in the bone cortex, was found in three cases. ${ }^{(1,3,5)}$ The anatomic location of the lesions was exclusively at the diaphysis in cases where the tibia and femur were involved. ${ }^{(1-5)}$ The other two cases of primary intraosseous AVMs involving the humerus and radius arose from 

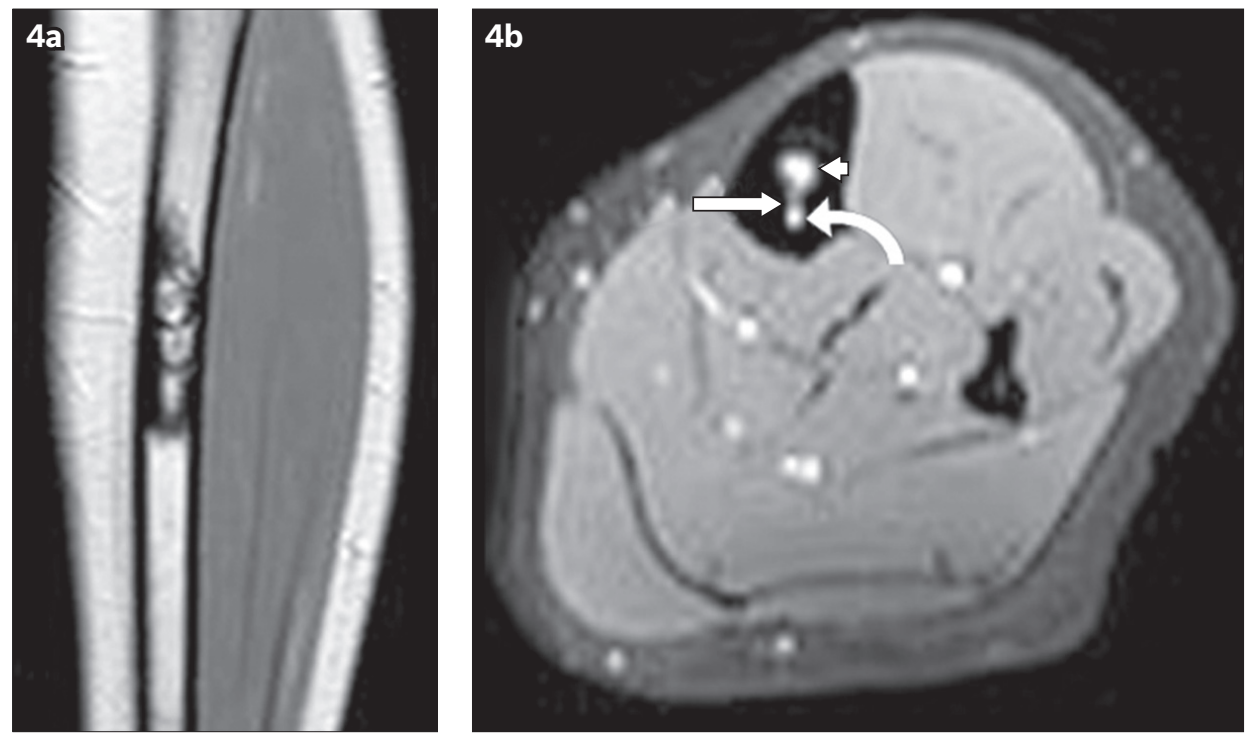

Fig. 4 (a) Coronal post-contrast-enhanced T1-W MR image shows the lesion with central enhancement and a non-enhancing peripheral margin. (b) Axial post-contrast-enhanced fat-saturated T1-W MR image shows the connecting vessel (arrow) between the lesion (arrowhead) and the branch of the anterior tibial vein (curved arrow)
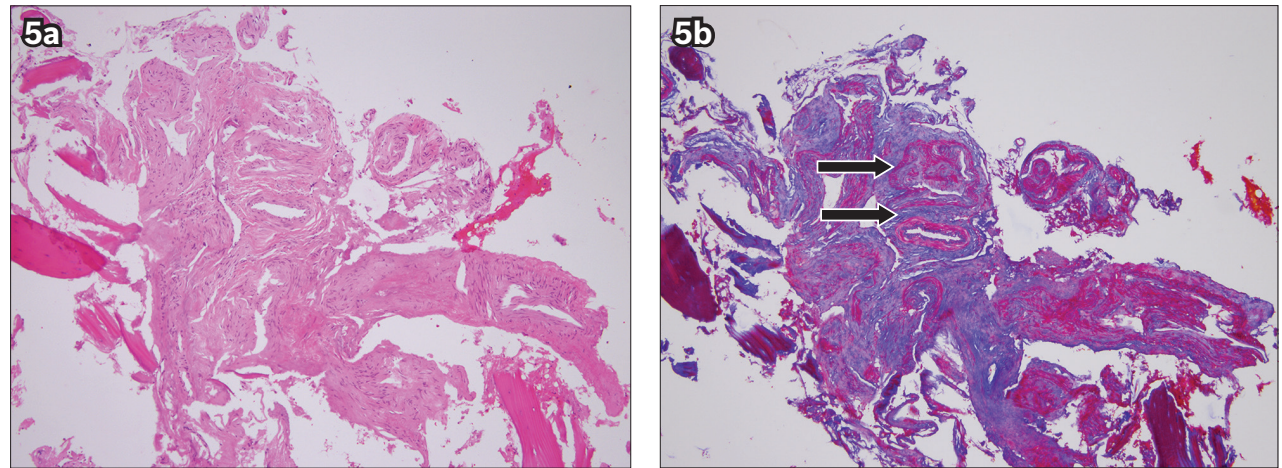

Fig. 5 Photomicrographs show (a) the intraosseous lesion composed of crowded blood vessels of variable sizes and shapes (Haematoxylin \& eosin, × 100); and (b) the presence of elastic laminae and fibres in the thickened arterial and venous walls (arrows) (Masson's trichrome stain, × 100).

the metadiaphysis. ${ }^{(4)}$ Primary intraosseous AVMs of the spine were demonstrated as purely lytic or mixed lytic, and sclerotic lesions with a sclerotic margin, distinct from the coarse trabeculations with a corduroy pattern of intraosseous haemangiomas of the spine. ${ }^{(6,7)}$ Neither aggressive periosteal reactions nor associated soft tissue masses were found in the ten reported cases.

The AVM in our patient presented on radiography as a solitary, nonaggressive central diaphyseal lytic lesion of the long bone with a thick sclerotic border. The differential diagnosis included fibrous dysplasia, fibroxanthoma, osteofibrous dysplasia, adamantinoma, desmoplastic fibroma and vascular tumour. These fibrous lesions of the bone appear osteolytic on plain radiography and often involve the anterior tibia. Vascular tumours of the tibia are relatively rare and mimic fibrous tumours on plain radiography, which means that they are often misdiagnosed. MR imaging is very sensitive in the detection of intramedullary pathology, and to the best of our knowledge, our report is the first to illustrate the MR features of primary intraosseous AVM in the radiologic literature. Only four reported cases (including the present case) have been examined by MR imaging, and exclusively demonstrated a lesion with isointensity or hypointensity on T1-weighted imaging and hyperintensity on T2-weighted imaging. ${ }^{(1,2,7)}$ However, in these four cases, the most perceptible MR imaging features characteristic of soft tissue AVMs - a tangle of multiple signal voids representing the dysplastic vessels in the centre of the lesion, associated with dilated tortuous feeding arteries and draining veins - could not be detected. In our case, the presence of a connecting vessel between the normal deep venous system of the lower extremity and the lesion is a clue that aids in the early diagnosis of primary intraosseous AVM.

The mainstay of therapy for patients with primary intraosseous AVMs includes conservative therapy, intra-arterial embolisation, surgery, and a combination of these treatments. Ivalon, n-butyl 2-cyanoacrylate (glue), Spongostan, ethanol and microcoils are the most commonly used embolic agents. The potential complications of intra-arterial embolisation include soft tissue infection, osteomyelitis, osteonecrosis and recurrent bleeding, but the most common complication is skin injury with a $10 \%$ incidence rate. The endothelium in intraosseous AVMs is not hyperplastic. These cells have a normal turnover rate, and are thus no more susceptible to antiproliferative treatments than the surrounding tissues. This renders treatments such as radiation 
Table I. Findings in the reported cases of intraosseous arteriovenous malformations.

\begin{tabular}{|c|c|c|c|c|c|c|c|c|c|}
\hline Study & $\begin{array}{l}\text { Gender/ } \\
\text { age }(y r)\end{array}$ & Site & Pain & $\begin{array}{l}\text { Pulsatile } \\
\text { mass }\end{array}$ & Radiography & Magnetic resonance imaging & Angiography & $\begin{array}{l}\text { Bone } \\
\text { scan }\end{array}$ & Treatment \\
\hline Present case & $F / 20$ & $\begin{array}{l}\text { Tibia/ } \\
\text { diaphysis }\end{array}$ & No & No & $\begin{array}{l}\text { Central medullary lytic lesion } \\
\text { with thick sclerotic margin }\end{array}$ & $\begin{array}{l}\text { Isointense lesion on T1-W, } \\
\text { hyperintense lesion on T2-W with } \\
\text { a connecting vessel to the normal } \\
\text { arterial system of the lower extremity }\end{array}$ & NA & IU & $\begin{array}{l}\text { Surgical } \\
\text { resection }\end{array}$ \\
\hline Knych et $\mathrm{al}^{(1)}$ & $\mathrm{M} / 7$ & $\begin{array}{l}\text { Tibia/ } \\
\text { diaphysis }\end{array}$ & Yes & No & $\begin{array}{l}\text { Central medullary lytic lesion, } \\
\text { hypertrophic nutrient artery } \\
\text { groove }\end{array}$ & $\begin{array}{l}\text { Hypointense lesion on T1-W and } \\
\text { slightly hyperintense lesion on } \mathrm{T} 2-\mathrm{W}\end{array}$ & NA & IU & $\begin{array}{l}\text { Surgical } \\
\text { resection }\end{array}$ \\
\hline $\begin{array}{l}\text { Matsuyama } \\
\text { et } \mathrm{al}^{(2)}\end{array}$ & $M / 15$ & $\begin{array}{l}\text { Tibia/ } \\
\text { diaphysis }\end{array}$ & Yes & No & $\begin{array}{l}\text { Central medullary } \\
\text { honeycomb lytic lesion, } \\
\text { cortical thinning, slight bony } \\
\text { expansion }\end{array}$ & $\begin{array}{l}\text { Isointense lesion on T1-W, } \\
\text { hyperintense lesion on } \mathrm{T} 2-\mathrm{W} \text { with } \\
\text { nodular and linear hypointense areas } \\
\text { on both } \mathrm{T} 1-\mathrm{W} \text { and } \mathrm{T} 2-\mathrm{W}\end{array}$ & Faint stain of the lesion & NA & $\begin{array}{l}\text { Surgical } \\
\text { curettage }\end{array}$ \\
\hline $\begin{array}{l}\text { Katzen and } \\
\text { Said }^{(3)}\end{array}$ & $F / 28$ & $\begin{array}{l}\text { Tibia/ } \\
\text { diaphysis }\end{array}$ & Yes & Yes & $\begin{array}{l}\text { Central medullary lytic lesion, } \\
\text { hypertrophic nutrient artery } \\
\text { groove, cortical defect }\end{array}$ & NA & $\begin{array}{l}\text { Early arteriovenous } \\
\text { shunting, hypertrophied } \\
\text { nutrient artery }\end{array}$ & IU & $\begin{array}{l}\text { Embolisation } \\
\text { (Gelfoam) }\end{array}$ \\
\hline \multirow[t]{3}{*}{$\begin{array}{l}\text { Savader } \\
\text { et } \mathrm{al}^{(4)}\end{array}$} & $\mathrm{M} / 14$ & $\begin{array}{l}\text { Tibia/ } \\
\text { diaphysis }\end{array}$ & Yes & Yes & Central medullary lytic lesion & NA & $\begin{array}{l}\text { Early arteriovenous } \\
\text { shunting }\end{array}$ & IU & $\begin{array}{l}\text { Conservative } \\
\text { treatment }\end{array}$ \\
\hline & $F / 28$ & $\begin{array}{l}\text { Humerus/ } \\
\text { metadiaphysis }\end{array}$ & Yes & No & $\begin{array}{l}\text { Central medullary lytic lesion } \\
\text { with thick sclerotic margin }\end{array}$ & NA & $\begin{array}{l}\text { Early arteriovenous } \\
\text { shunting }\end{array}$ & IU & $\begin{array}{l}\text { Conservative } \\
\text { treatment }\end{array}$ \\
\hline & $F / 22$ & $\begin{array}{l}\text { Radius/ } \\
\text { metadiaphysis }\end{array}$ & Yes & Yes & Central medullary lytic lesion & NA & $\begin{array}{l}\text { Early arteriovenous } \\
\text { shunting }\end{array}$ & NA & $\begin{array}{l}\text { Conservative } \\
\text { treatment }\end{array}$ \\
\hline $\begin{array}{l}\text { Nancarrow } \\
\text { et al(5) }\end{array}$ & $F / 9$ & $\begin{array}{l}\text { Femur/ } \\
\text { diaphysis }\end{array}$ & No & Yes & $\begin{array}{l}\text { Small central medullary lytic } \\
\text { lesion, hypertrophic nutrient } \\
\text { artery groove }\end{array}$ & NA & $\begin{array}{l}\text { Early arteriovenous } \\
\text { shunting, hypertrophied } \\
\text { nutrient artery }\end{array}$ & IU & $\begin{array}{l}\text { Embolisation } \\
\text { (coils and } \\
\text { Avitene) }\end{array}$ \\
\hline Molina et $\mathrm{al}^{(6)}$ & $\mathrm{M} / 8$ & $\begin{array}{l}\text { Vertebra L4/ } \\
\text { lamina }\end{array}$ & Yes & No & $\begin{array}{l}\text { Round lytic lesion with thick } \\
\text { sclerotic margin }\end{array}$ & NA & NA & IU & $\begin{array}{l}\text { Surgical } \\
\text { resection }\end{array}$ \\
\hline Louis et $\mathrm{al}^{(7)}$ & $F / 59$ & $\begin{array}{l}\text { Vertebra T5/ } \\
\text { posterior } \\
\text { element }\end{array}$ & Yes & No & $\begin{array}{l}\text { Expansive mixed lytic and } \\
\text { sclerotic lesion with anterior } \\
\text { sclerotic margin (on CT), } \\
\text { cortical erosion }\end{array}$ & $\begin{array}{l}\text { Isointense lesion on } \mathrm{T} 1-\mathrm{W} \text { and } \\
\text { hyperintense lesion on } \mathrm{T} 2 \mathrm{-W}\end{array}$ & $\begin{array}{l}\text { Feeding artery from T5 } \\
\text { intercostal artery }\end{array}$ & NA & $\begin{array}{l}\text { Embolisation } \\
\text { (coils) and } \\
\text { surgical } \\
\text { resection }\end{array}$ \\
\hline
\end{tabular}


and chemotherapy ineffective. ${ }^{(14)}$ Total surgical resection is generally considered the optimal therapy for AVMs because of their tendency to expand and recur with time. Intra-arterial embolisation has met with promising success as both an adjunct to surgery and the primary therapy.

We described a rare case of primary intraosseous AVM involving the diaphysis of the tibia, with radiographic features mimicking a fibrous tumour. With intraosseous AVM, the imaging features typical of a soft tissue AVM are frequently absent, making diagnosis difficult. However, the presence of peculiar MR features, such as a connecting vessel between the normal deep venous system of the lower extremity and the tumour, aids in the early diagnosis of primary intraosseous AVM. Knowledge of its radiographic and MR imaging features can help in the early recognition of this exceptional entity preoperatively, prevent unnecessary biopsy (which carries with it the risk of potentially large haemorrhage), and allow adequate treatment via either transcatheter embolisation or surgery.

\section{REFERENCES}

1. Knych SA, Goldberg MJ, Wolfe HJ. Intraosseous arteriovenous malformation in a pediatric patient. Clin Orthop Relat Res 1992; 276:307-12.

2. Matsuyama A, Aoki T, Hisaoka M, Yokoyama K, Hashimoto H. A case of intraosseous arteriovenous malformation with unusual radiological presentation of low blood flow. Pathol Res Pract 2008; 204:423-6.

3. Katzen BT, Said S. Arteriovenous malformation of bone: an experience with therapeutic embolization. AJR Am J Roentgenol 1981; 136:427-9.

4. Savader SJ, Savader BL, Otero RR. Intraosseous arteriovenous malformations mimicking malignant disease. Acta Radiol 1988; 29:109-14.

5. Nancarrow PA, Lock JE, Fellows KE. Embolization of an intraosseous arterivenous malformation. AJR Am J Roentgenol 1986; 146:785-6.

6. Molina A, Martin C, Muñoz I, et al. Spinal intraosseous arteriovenous malformation as a cause of juvenile scoliosis: a case report. Spine (Phila Pa 1976) 1997; 15:221-4

7. Louis RG Jr, Yen CP, Mohila CA, Mandell JW, Sheehan J. A rare intraosseous arteriovenous malformation of the spine. J Neurosurg Spine 2011; 15:336-9.

8. Mulliken JB, Glowacki J. Hemangiomas and vascular malformations in infants and children: a classification based on endothelial characteristics. Plast Reconstr Surg 1982; 69:412-20.

9. Finn MC, Glowacki J, Mulliken JB. Congenital vascular lesions: clinical application of a new classification. J Pediatr Surg 1983; 18:894-900.

10. Inoue $Y$, Ohtake T, Wakita S, et al. Flow characteristics of soft-tissue vascular anomalies evaluated by direct puncture scintigraphy. Eur J Nucl Med 1997; 24:505-10.

11. Baker LL, Dillon WP, Hieshima GB, Dowd CF, Frieden IJ. Hemangiomas and vascular malformations of the head and neck: MR characterization. AJNR Am J Neuroradiol 1993; 14:307-14.

12. Rak KM, Yakes WF, Ray RL, et al. MR imaging of symptomatic peripheral vascular malformations. AJR Am J Roentgenol 1992; 159:107-12.

13. Donnelly LF, Adams DM, Bisset GS 3rd. Vascular malformations and hemangiomas: a practical approach in a multidisciplinary clinic. AJR Am J Roentgenol 2000; 174:597-608.

14. Gampper TJ, Morgan RF. Vascular anomalies: hemangiomas. Plast Reconstr Surg 2002; 110:572-85 